\title{
OVERVIEW AND TRENDS IN AUTOMOTIVE GEARBOXES OF STANDARD POWERTRAINS
}

\section{GABRIELA ACHTENOVÁ}

Czech Technical University in Prague, Technická 4, CZ-166 07, Prague 6, Czech Republic, E-mail: Gabriela.achtenova@fs.cvut.cz

\section{SHRNUTí}

Článek shrnuje výsledek statistických dat čerpaných zejména z katalogu Revue Automobile z let 1995, 2000, 2005, 2012, 2015. Shromážděná data dávají přehled o vývoji a trendech technických parametrů převodovek osobních vozidel. Pouze "klasická" hnací ústrojí, kde zdrojem energie je spalovací motor jsou zahrnuta do této studie. Hybridizace nebo elektrifikace vozidel na počátku této statistiky neexistovala nebo jen ve zcela výjimečných prípadech.

\section{KLICČOVÁ SLOVA: PŘEVODOVKY OSOBNÍCH AUTOMOBILŮ, HNACI ÚSTROJÍ SE SPALOVACIMM MOTOREM, STATISTICKÉ ÚDAJE}

\section{ABSTRACT}

In this article we present an overview and summarize trends in automotive gearboxes of standard powertrains. The majority of data used in the statistics are obtained from Catalogue de la Revue Automobile published in years 1995, 2000, 2005, 2012 and 2015. Observed statistical data gives overview about trends in technical parameter of automotive transmissions. Only "standard powertrains", where the only energy source is the internal combustion engines are taken into account. The hybridization or electrification of powertrains was not an issue on the beginning of the study.

KEYWORDS: PASSENGER CAR GEARBOXES, POWERTRAINS WITH INTERNAL COMBUSTION ENGINE, STATISTICAL DATA

\section{INTRODUCTION}

In the first years of the $21^{\text {st }}$ century, a remarkable increase of different transmission solutions occurred in serially produced cars. Obviously, most of the ideas were invented in the last two decades of the $20^{\text {th }}$ century, but as can be clearly seen from Figure 1, the realisation and market introduction did not begin until the start of the $21^{\text {st }}$ century.

The reasons why after 60 years of slow evolution such a relatively brief period of intensive transmission research occurred seems to lie in the technological developments in combination with global economic and political situation:

- Growth of the new domain of mechatronics became possible thanks to the fast progress of electronics and microelectronics in the last decades of the $20^{\text {th }}$ century. Mechatronics are critical to the improvement of control and actuation of transmissions, in terms of acceptable shift comfort of automated transmissions for the passenger car driver.

- During the observed last 20 years the internal combustion engine (ICE) remained the main energy source. For the short- and medium-term future a revolution in the power unit is not likely to occur. In last years, many new ideas and different powertrain solutions are proposed based on hybrid powertrains or pure electric drives. The amount of these vehicles will grow, however, very much depending on the change of existing infrastructure, and on the willingness of customers to accept new types of powertrains.

- The revolutionary growth of diversity of proposed powertrains can be further explained in the limits of crude oil and political instability in some areas of its deposits, which have lead developments of ICE away from achieving more power to efficiency improvements. The transmission efficiency, the gearbox spread, and the number of gears are getting more important for the evaluation of the driveline.

- Because of the emergence of intercontinental automotive concerns which use one vehicle platform for different car brands and types (the trend started mainly because of the economic recession at the end of $20^{\text {th }}$ century) the power-weight ratio of vehicles has become basically uniform for all continents (e.g. in the 1960 'ies the power-weight ratio of US cars was 
twice that of European passenger vehicles). Engines are downsized and transmission efficiency now plays an important role in car performance and fuel consumption. The whole drive-line has become subject of efficiency increase.

- To stabilise environmental changes caused by emissions of noxious gases the governments worldwide introduced emission limits. The tightest limits are imposed in Europe.

- Mobility has strongly increased and is now often considered a necessity. The need to manage the huge increase of transport could lead in the future to traffic supervisors, which may even intervene in the vehicle driveline, e.g. to change the vehicle speed according to instantaneous conditions like jams, accidents, weather, etc. Fully automatic driveline control then becomes a necessity, which may lead to complete replacement of manual transmissions by automatic controlled ones.

- Mastering of previously known principle of dual clutch transmission to the level that it could be used in serially produced cars make a huge competitor to standard automatic transmission.

- Mastering of computer synthesis of stepped planetary gearboxes kept the position of automatic transmissions on the market.
The evolution of the passenger car transmission market in the last 20 years is shown in the following graphs. The car parameters were taken from [1], [2], [3], [4] and [5] corresponding to the years 1995, 2000, 2005, 2012 and 2015. The parameters of more than 700 passenger car types in every chosen year were processed and statistically evaluated. The involved vehicles are all passenger car types. Terrain vehicles, SUVs, vans and cabrios were excluded. From the data we derive an overview of number of different transmission types corresponding to the number of different brands and models. It is important to note that the total volume of produced gear-boxes is not taken into consideration, but only the number of different types (thus, luxury models produced in low amount such as by McLaren or Ferrari count as much as mass produced models). Most of the studies published relies on the market share or on the number of produced units. These statistics are based on technical data, and on amount of vehicle types in which concerned transmissions are used. The overview concerning production figures up to 2004 can be found in for example [8].

We differentiate the transmissions into the following groups: $M=$ mechanical driver shifted transmission; $A=$ automatic transmission (generally transmissions which consists from planetary gearsets and hydrodynamic torque converter. Important point is that gearshift is powershift); AMT = automated

\section{DIFFERENT TRANSMISSION SYSTEMS IN THE VEHICLES IN LAST 20 YEARS}

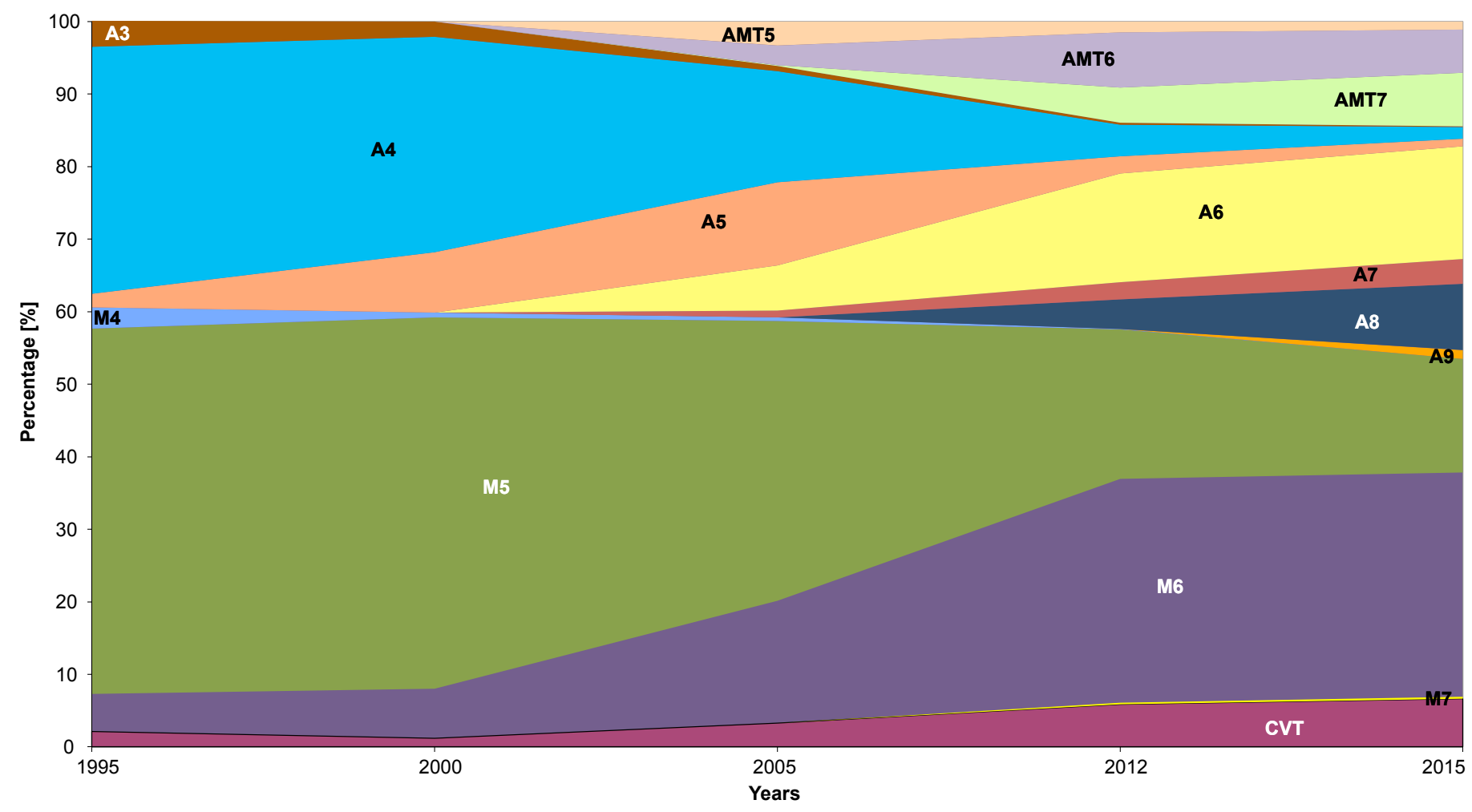

FIGURE 1: Evolution of the amount of transmission types in last 20 years.

OBRÁZEK 1: Vývoj nasazení různých typů převodovek za posledních 20 let. 
SPECIFIC POWER

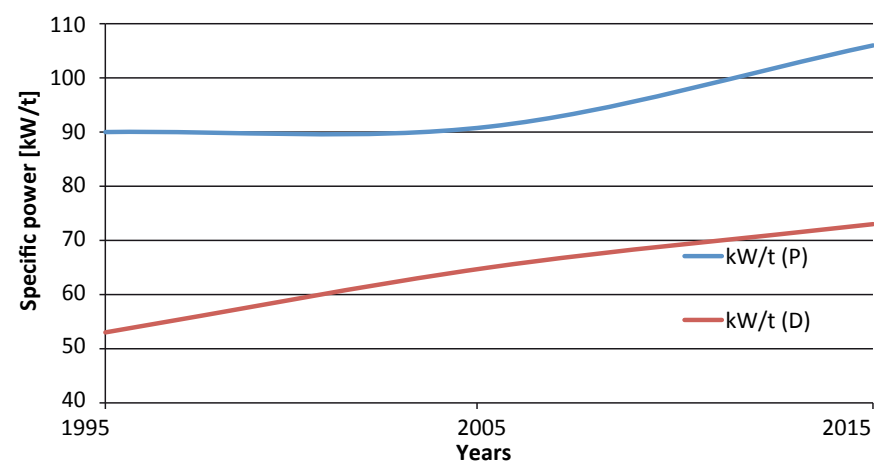

FIGURE 2: Changes of mean specific power of petrol (P) and diesel (D) engines of passenger cars during last two decades.

OBRÁZEK 2: Změny průměrné hodnoty měrného výkonu u zážehových $(P)$ a vznětových (D) motorů osobních vozidel.

\section{REPRESENTATION OF ENGINES IN VEHICLES}

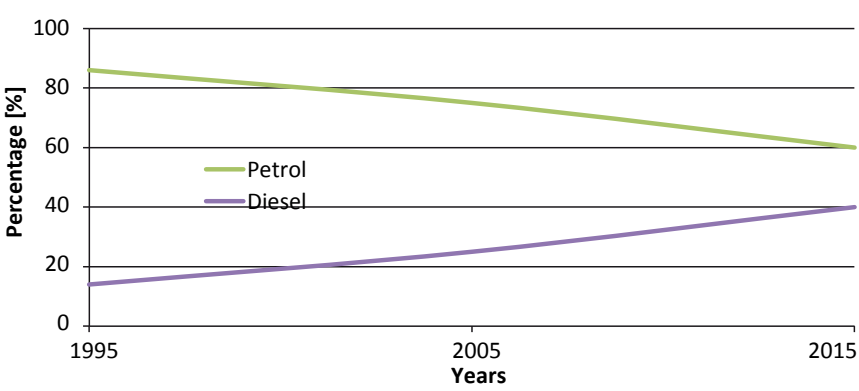

FIGURE 3: Representation of usage of petrol and diesel engines in passenger vehicle models in last two decades.

OBRÁZEK 3: Poměr použití zážehových a vznětových motorů v modelech osobních vozidel v posledních 20 letech.

\section{MEAN ENGINE TOQUE RELATED TO DIFFERENT TRANSMISSION TYPES}

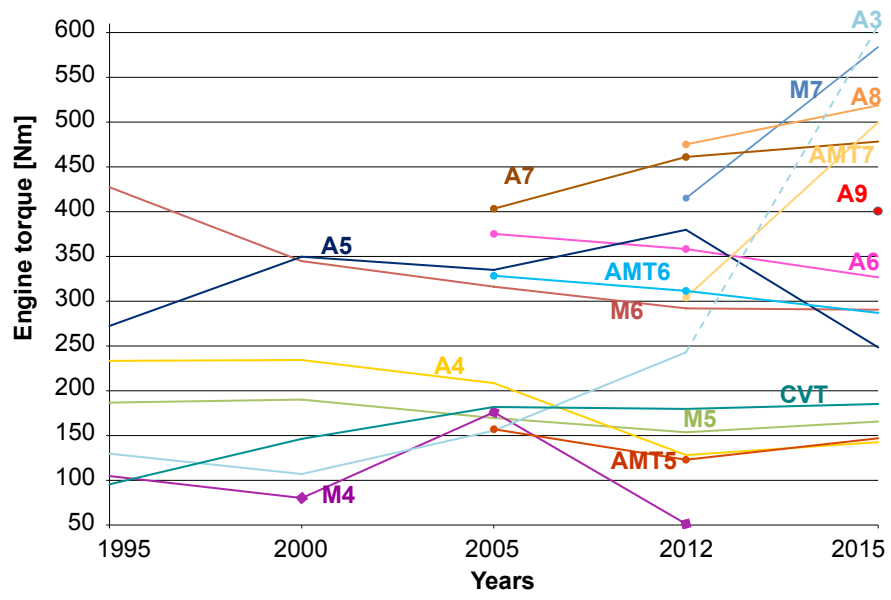

FIGURE 4: Mean value of transmitted torque by different transmission types during last two decades.

OBRÁZZK 4: Střední hodnota přenášeného točivého momentu jednotlivými druhy převodného ústrojí za posledních 20 let.

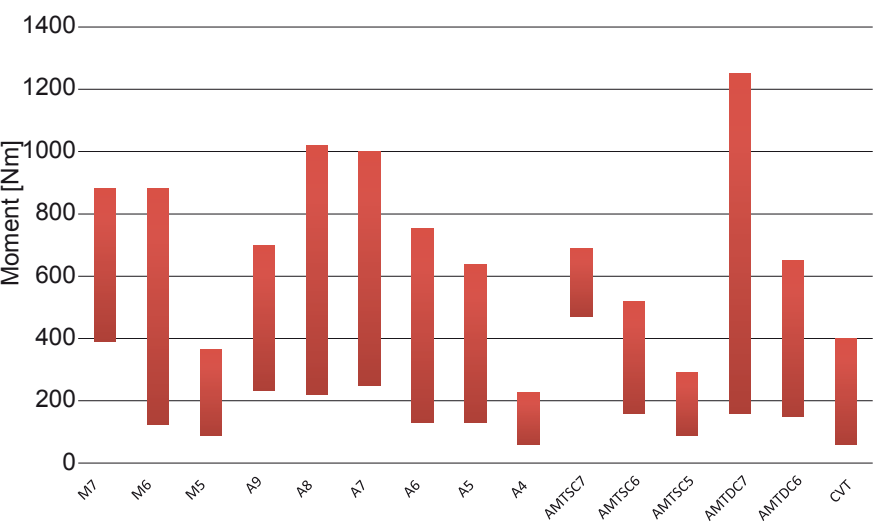

FIGURE 5: Torque range for different transmission types in 2015. OBRÁZEK 5: Rozsah točivého momentu různých převodných ústrojí $v$ roce 2015.

transmission (in this group belong the classical automated transmissions with single automated clutch, but also the dual clutch transmissions. The decisive point is that driver has two pedal vehicle with a gearbox where the gearshift occurs with interruption of torque flow); CVT = Continuously variable transmission of any existing type.

For models where more engine variants are offered, the least powerful and the most powerful version of both petrol and diesel engines were taken. As can be seen in Figure 1, between the years 1995 and 2000 the choice of transmissions remained the same: Manual Transmissions (MT) having 6, 5 and 4-speeds, Automatic Transmissions (AT) with 5, 4 and 3-speeds and Continuously Variable Transmissions (CVT). From the year 2000 till 2005 the offer increased with 6 and 7-speed automatic transmissions, Automated Mechanical Transmissions (AMT) - Dual clutch or the gearboxes with shifting with interruption of torque flow - having 7, 6 or 5 -speeds. In the most recent years the offer even increased more. The successful introduction of dual transmission on the market, together with mastering of synthesis of planetary sets "woke up" the segment of automatic transmissions. The variants with 7, 8 and 9-speeds were introduced on the market. The amount of the speeds of automatic transmissions is not final, as can be seen for example in this year's introduced 10-speed AT from Ford.

\section{ENGINE PARAMETERS}

To be able to fully understand the development in the transmissions, we have to briefly look on the changes of engine parameters during the years. In the years 1995, 2005 and 2015 we observed also the curb weight of vehicles, wherefrom the specific power was calculated. The amount of 


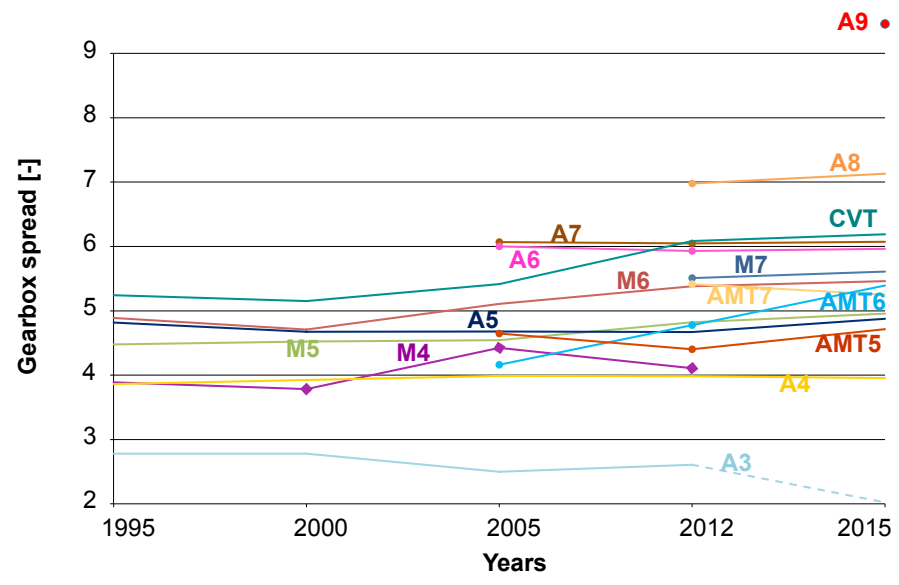

FIGURE 6: Evolution of gearbox spread in different transmission types. OBRÁZEK 6: Vývoj rozsahu jednotlivých druhů převodovek.

\section{RANGE OF SPREAD IN SERIALLY PRODUCED TRANSMISSION IN 2015}

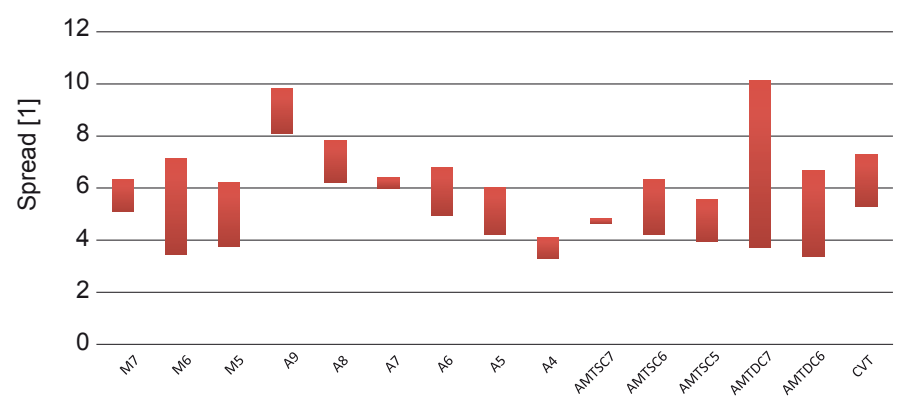

FIGURE 7: The range of spread of all type of transmissions for passenger cars produced in 2015.

OBRÁZEK 7: Rozpětí rozsahu všech typů převodovek sériově vyráběných $v$ roce 2015 v osobních vozidlech.

MEAN VALUE OF GEARBOX SPREAD RELATED WITH NUMBER OF SPEEDS

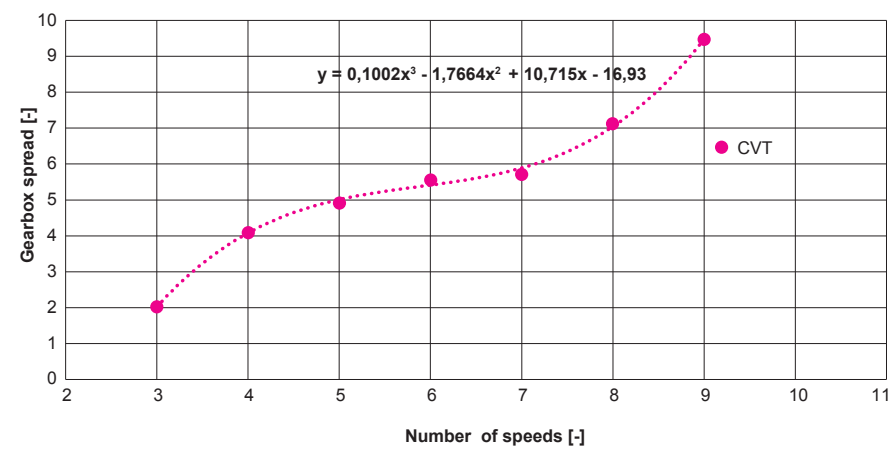

FIGURE 8: Relation of gearbox spread on number of speeds. OBRÁZEK 8: Závislost rozsahu převodovky na počtu rychlostních stupňů. observed vehicles has increased. In the year 1995 we treated in the statistics about 750 models, whilst in the year 2015 the number of relevant models has increased to 1350. The graphs on Figures 2 and 3 show the outcomes concerning the percentage of the representation of diesel and petrol engine in different models (again no reference to number of produced pieces). Further we determined the evolution of specific power during last 20 years for diesel and petrol engines. Wherefrom we can clearly see, that the mean of specific power of diesel engines was constantly growing, although the graph in last decade has smaller progression factor. Petrol engines at the end of last century kept the mean specific power constant. In last decade, we can observe important growth of specific power.

From Figure 3 we can observe the increase of usage of diesel engine. More precise the number of serially produced models equipped with diesel engine doubled the amount used in the year 1995.

\section{TRANSMISSION PARAMETERS}

The next interesting trend concerns the relationship between mean value of transmitted torque and the transmission type during the years (Figure 4). The curves of 6-speed manual transmission have a downward trend, which means that from the class of luxury powerful cars the six speed transmissions move to the range of medium passenger car class. The upward curve of CVT shows the increasing development of the frictional transmission. The upward trend of 4 and 5 -speed automatic gearboxes is interrupted in 2000, when automatic and automated gearboxes with higher number of speeds were introduced on the market.

In all cases it is necessary to treat the values in newcomers, or values of almost obsolete models very carefully. For example, the 3-speed automatic transmission is in last decade used only in ZIL 4104. Therefore, we cannot really speak about mean values, since it concerns only one type and one engine. The newcomer transmissions like 8 and 9-speed automatic transmissions are in the early stage of their usage limited to upper class vehicles only. As example we can cite the A9 (9-speed automatic transmission). This gearbox was in 2015 used only in following type of vehicles: Chrysler 200, Jeep Renegade, Land Rover models and Mercedes E-class.

We can observe a strong increase of torque for AMT7; this can be explained by two facts. The usage of AMT7 is still relatively limited, so any vehicle with very high or very low torque can influence the result. In the year 2015 the 7-speed dual clutch transmission was used in Bugatti Veyron. Its $850 \mathrm{Nm}$ influences the shape of the mean torque of this transmission. 
How big the range of torques of different transmission types can be is shown in Figure 5. This Figure is related to year 2015 only. In this graph are also clearly separated the AMT transmissions with single clutch and double clutch transmissions. The torque introduced in Figure 4 is just averaged value.

An important parameter for any gearbox is its spread. In Figure 6 we can observe the evolution. In this case we have to be even more careful about values for newcomer transmissions. The 8 and 9-speed automatic transmissions exist (or in model year 2015 existed) only in one or maximally two combinations of gear ratios.

The spread for different transmission types can be very tight, something which is depicted clearly in Figure 7. In this figure we can observe the range of spread of different transmission types used in the year 2015. The narrower field of the range the less variants of the gearbox exists.

The interest of more speed transmissions is to obtain high transmission spread, which will allow better adherence to the traction hyperbola, and to better use the sweet point of internal combustion engine. Figure 8 shows the relation between the mean spread and the number of speeds. The values were taken from the year 2015. All types of gearbox with the same number of speeds were averaged. For the stepped transmissions we can very roughly say, that the spread of transmission is approximately equal the number of speeds (just forward speeds counted). As in the year 2015 were not yet introduced the 10-speed gearboxes, we kept this column to show the averaged spread of all CVT systems in 2015.

\section{CONCLUSION}

In this paper we presented an overview and summarized trends in automotive gearboxes of standard powertrains, based on data mainly taken from Catalogue de la Revue Automobile published in years 1995, 2000, 2005, 2012 and 2015. Observed statistical data gives overview about trends in technical parameter of automotive transmissions. In 1995 existed on the market of serial produced vehicles 3 types of transmissions: mechanical, automatic and CVT'S. Mechanical ones were available in 4-, 5- and 6-speed variants, automatic planetary power shifted gearboxes existed in 3-, 4- and 5 -speed variants. Totally were on the market 7 transmission variants. If we will group together the automated single and double clutch transmissions, then the amount of proposed transmission variants in 2015 just doubled the amount of 20 years ago. In the year 2015 the customers could choose from 3- to 9-speed automatic transmissions, 5- to 7-speed mechanical manually shifted gearboxes, 5- to 7-speed automated transmissions, and CVT's. If we will separate

the automated single clutch gearboxes and double clutch transmissions, then we can count till 17 different gearbox variants on the market. During the years completely disappeared the 4-speed manually gearboxes. The 3-speed automatic gearbox is offered in one last vehicle type. The huge diversity on the market is in last period further enlarged by introduction of hybrid or electric vehicles, which are not included in this statistics.

\section{LIST OF ABBREVIATIONS}

$\mathrm{M}$

AMT Automated transmission (Single or double clutch)

AMTSC Automated single clutch transmission

AMTDC Double clutch transmission

A Automatic powershift transmission

CVT Continuously Variable Transmission

\section{ACKNOWLED GEMENTS}

This research has been realized using the support of The Ministry of Education, Youth and Sports program NPU I (LO), project L01311: 'Development of Centre of Vehicles for Sustainable Mobility'.

The support is gratefully acknowledged.

\section{REFERENCES}

[1] Katalog der Automobil Revue. Hallwag AG, Bern, ISBN 3-444-10444-8, 1995

[2] Katalog der Automobil Revue. Hallwag AG, Bern, ISBN 3-444-105896-x, 2000

[3] Katalog der Automobil Revue. Büchler Grafino AG, Bern, ISBN 3-905 386-05-4, 2005

[4] Katalog der Automobil Revue, ISBN 978-3613307186, 2012

[5] Katalog der Automobil Revue. Motorbuch Verlag, ISBN 978-3-613-30792-6, 2015

[6] Sytný M., Přehled a trendy ve vývoji převodovek osobních automobilů, BP ČVUT v Praze, 2013

[7] Kotrč J., Přehled a trendy ve vývoji převodovek osobních automobile, BP ČVUT v Praze, 2016

[8] Naunheimer H., Bertsche B., Ryborz J., Novak W., Automotive Transmissions, Springer Verlag, ISBN 978-3-642-16213-8, 2011 